Short communication

\section{A Rapid Agglutinating Antibody- detection Method for the Diagnosis of Streptococcus dysgalactiae Infection in Farmed Fish Using Recombinant Surface Immunogenic Protein (rSd-Sip) -coated Latex Beads}

\author{
Issei Nishiki ${ }^{1}$, Takayuki Minami ${ }^{2}$, Toshiaki Itami ${ }^{3}$ \\ and Terutoyo Yoshida ${ }^{3 *}$ \\ ${ }^{1}$ Interdisciplinary Graduate School of Agriculture and \\ Engineering, University of Miyazaki, \\ Miyazaki 889-2192, Japan \\ ${ }^{2}$ Miyazaki Prefectural Fisheries Experimental Station, \\ Miyazaki 889-2162, Japan \\ ${ }^{3}$ Faculty of Agriculture, University of Miyazaki, \\ Miyazaki 889-2192, Japan
}

(Received December 16, 2013)

\begin{abstract}
To develop a rapid diagnosis method for Lancefield group C Streptococcus dysgalactiae (GCSD) infection, latex beads were coated with recombinant $S$. dysgalactiae surface immunogenic protein (rSd-Sip). The usefulness of the beads for slide agglutination tests with fish sera was examined. The beads were agglutinated with GCSD-infected sera collected from farmed amberjack Seriola dumerili. However, the beads were not agglutinated with non-infected sera or immunized sera collected from fish vaccinated with Lactococcus garvieae and Streptococcus iniae. The results demonstrate that the slide agglutination test using rSd-Sip-coated latex beads is an easy, rapid, and effective method for agglutinating antibody-detection in GCSD-infected fish.
\end{abstract}

Key words: Streptococcus dysgalactiae, Seriola dumerili, serodiagnosis, latex agglutination test, surface immunogenic protein

The first outbreak of Lancefield group C Streptococcus dysgalactiae (GCSD) infection in Japan was confirmed in 2002 (Nomoto et al., 2004, 2006, 2008). The GCSD

\footnotetext{
* Corresponding author

E-mail: t-yosh@cc.miyazaki-u.ac.jp
}

infection became an important fish disease affecting cultured fish species in the genus Seriola, such as amberjack S. dumerili, yellowtail S. quinqueradiata, and kingfish $S$. lalandi. This infectious disease has resulted in economic damage to fish farms in Japan. To minimize any economic loss due to GCSD infection, a rapid and easy diagnostic method should be developed in order to detect GCSD infection.

Unfortunately, the symptoms of GCSD infection in fish are similar to those of the Lactococcus garvieae infection in farmed amberjack (Nomoto et al., 2004). In addition, the colony morphology of these causal pathogens could not be used to discriminate between the two different diseases. Therefore, GCSD infection in farmed fish cannot be rapidly diagnosed. A slide agglutination test using bacterial colonies and antiserum against a corresponding bacterium has often been used to rapidly identify the bacterial pathogen in diseased fish. However, GCSD cells isolated from fish are inapplicable to the slide agglutination test using antiserum because of their severe auto-aggregation (Nomoto et al., 2004).

In a previous study, a $S$. dysgalactiae surface immunogenic protein (Sd-Sip) of approximately $60 \mathrm{kDa}$ was identified (Nishiki et al., 2013). The Sd-Sip possessed a LysM domain, and all fish GCSD isolates expressed the Sd-Sip on their surfaces. Because SdSip elicited specific antibody production in GCSDinfected fish, an enzyme-linked immunosorbent assay (ELISA) using recombinant Sd-Sip (rSd-Sip) as a solidphase antigen was used to measure the antibody in GCSD-infected fish (Nishiki et al., 2013). In the present study, we coated latex beads with rSd-Sip and developed a rapid and easy antibody-detection method for GCSD infection at the pond side.

\section{Materials and Methods}

Coating of latex beads with $r$ Sd-Sip

rSd-Sip was generated by Escherichia coli BL21 as previously described (Nishiki et al., 2013). In addition, the coating of rSd-Sip onto latex beads was performed using the methods of Watari et al. (2007). Briefly, purified rSd-Sip was adjusted to a concentration of 300 $\mu \mathrm{g} / \mathrm{mL}$ with phosphate-buffered saline (PBS). Then, $300 \mu \mathrm{L}$ of $1 \%$ Polybead ${ }^{\circledR}$ Polystyrene $1.0-\mu \mathrm{m}$ Microspheres (Polysciences) and an equal volume of the antigen solution were mixed for $16 \mathrm{~h}$ at $20^{\circ} \mathrm{C}$ with rotation (10 rpm). Subsequently, the latex beads were washed three times with $1 \mathrm{~mL}$ of blocking buffer (PBS containing $1 \%$ bovine serum albumin, $0.01 \%$ Tween 20 , and $0.1 \%$ polyethylene glycol 6000) and centrifuged at $12,500 \times g$ for 15 min. After washing twice with PBS, rSd-Sip-coated latex particles were resuspended in $1 \mathrm{~mL}$ of blocking buffer to block any remaining latex protein-binding sites for $16 \mathrm{~h}$ at $20^{\circ} \mathrm{C}$ with rotation. The blocked latex particles were centrifuged as described above and diluted 5 
times with PBS (containing $0.1 \%$ sodium azide) and stored at $4^{\circ} \mathrm{C}$ until use.

\section{Preparation of fish serum}

For artificial infection, amberjack $(n=10)$ with an average body weight of approximately $150 \mathrm{~g}$ were acclimatized for one week in 250-L tanks of sea water at a temperature of $28 \pm 0.5^{\circ} \mathrm{C}$. During acclimatization, fish were fed daily with dry pellets. The GCSD 12-06 strain was cultured in Todd Hewitt broth (Difco) at $28^{\circ} \mathrm{C}$ for $30 \mathrm{~h}$. The bacterial cells were mixed with dry pellets and given to fish at a concentration of approximately $1 \times 10^{9} \mathrm{CFU} /$ fish for one day. Fish were maintained at the same temperature for 14 days and given full feedings without adding bacterial cells. During the observation period, blood was collected from dead and survived fish. After the clotting of blood, the serum was separated by centrifugation at $5,000 \times g$ for $20 \mathrm{~min}$. The separated serum was filtered using a $0.45-\mu \mathrm{m}$ filter. Bacteria were isolated from necrotic tissues of the causal peduncle or kidney of infected fish on ToddHewitt agar. Ten amberjack sera collected from noninfected fish were used as controls for the slide agglutination test.

Table 1. Sources of naturally infected sera used in this study

\begin{tabular}{cccc}
\hline $\begin{array}{c}\text { Amberjack } \\
\text { number }\end{array}$ & Location & Year/month & $\begin{array}{c}\text { Body weight } \\
(\mathrm{kg})\end{array}$ \\
\hline 1 & Miyazaki & 2012/June & 3.1 \\
2 & Miyazaki & 2012/June & 2.8 \\
3 & Miyazaki & 2012/June & 3.5 \\
4 & Miyazaki & 2012/July & 3.4 \\
5 & Kagoshima & 2013/July & 2.5 \\
6 & Kagoshima & 2013/July & 3.5 \\
7 & Kagoshima & 2013/July & 3.1 \\
8 & Kagoshima & 2013/July & 2.7 \\
9 & Kagoshima & 2013/July & 2.2 \\
10 & Kagoshima & 2013/July & 2.1 \\
\hline
\end{tabular}

Sera of naturally infected fish used in this study are listed in Table 1. These sera were collected from two different fish farms. All the amberjack exhibited the typical symptoms of GCSD infection, such as severe necrotic lesions in the caudal peduncle (Hagiwara et al., 2009, 2010). GCSD was isolated from the kidney and caudal peduncle of the amberjack.

\section{Agglutination test}

To confirm whether recombinant protein-coated latex beads were applicable to GCSD infection, sera collected from infected and non-infected fish were used for the slide agglutination test. First, $50 \mu \mathrm{L}$ of latex solution and an equal volume of sera collected from infected fish were mixed on a glass slide and incubated at room temperature for $15 \mathrm{~min}$ without shaking. Sera collected from non-infected fish were used as negative controls. In order to confirm that the rSd-Sip-coated latex beads could not cause cross-reactions to antibodies, which have been induced by other pathogenic antigens in fish, sera collected from fish that had been immunized using commercialized vaccines against $L$. garvieae and $S$. iniae were examined. The immunization of fish was performed as previously described (Nishiki et al., 2013). Samples that caused visible agglutination were considered positive.

To estimate the agglutination titers of GCSDinfected sera, the serum samples for the rSd-Sip-coated latex beads were determined using the micro-titer plate agglutination assay (Roberson, 1990). Agglutination reactions were performed at $25^{\circ} \mathrm{C}$ for $4 \mathrm{~h}$. After incubation, the plates were incubated at $4^{\circ} \mathrm{C}$ overnight, and agglutination was detected on a light viewer (Kenko) without shaking.

\section{Results and Discussion}

To estimate the sensitivity and specificity of the rSdSip-coated latex beads, the slide agglutination test was

Table 2. Results of artificial infection, slide agglutination test, and agglutination titers

\begin{tabular}{ccccccc}
\hline $\begin{array}{c}\text { Amberjack } \\
\text { number }\end{array}$ & $\begin{array}{c}\text { Dead or } \\
\text { survived }\end{array}$ & $\begin{array}{c}\text { Sampling } \\
\text { days after } \\
\text { infection }\end{array}$ & $\begin{array}{c}\text { GCSD } \\
\text { isolation }\end{array}$ & Symptom* & $\begin{array}{c}\text { Slide } \\
\text { agglutination } \\
\text { test }\end{array}$ & $\begin{array}{c}\text { Agglutination } \\
\text { titter }\end{array}$ \\
\hline 1 & Dead & 7 & + & - & + & $1: 32$ \\
2 & Dead & 7 & + & - & + & $1: 32$ \\
3 & Dead & 7 & + & + & + & $1: 32$ \\
4 & Dead & 10 & + & + & + & $1: 128$ \\
5 & Dead & 10 & + & + & + & $1: 512$ \\
6 & Dead & 11 & + & - & + & $1: 64$ \\
7 & Survived & 14 & - & - & + & $1: 8$ \\
8 & Survived & 14 & - & - & + & $1: 32$ \\
9 & Survived & 14 & + & - & + & $1: 128$ \\
10 & Survived & 14 & - & - & + & $1: 16$ \\
\hline
\end{tabular}

*Symptom was a severe necrotic lesion of caudal peduncle. 


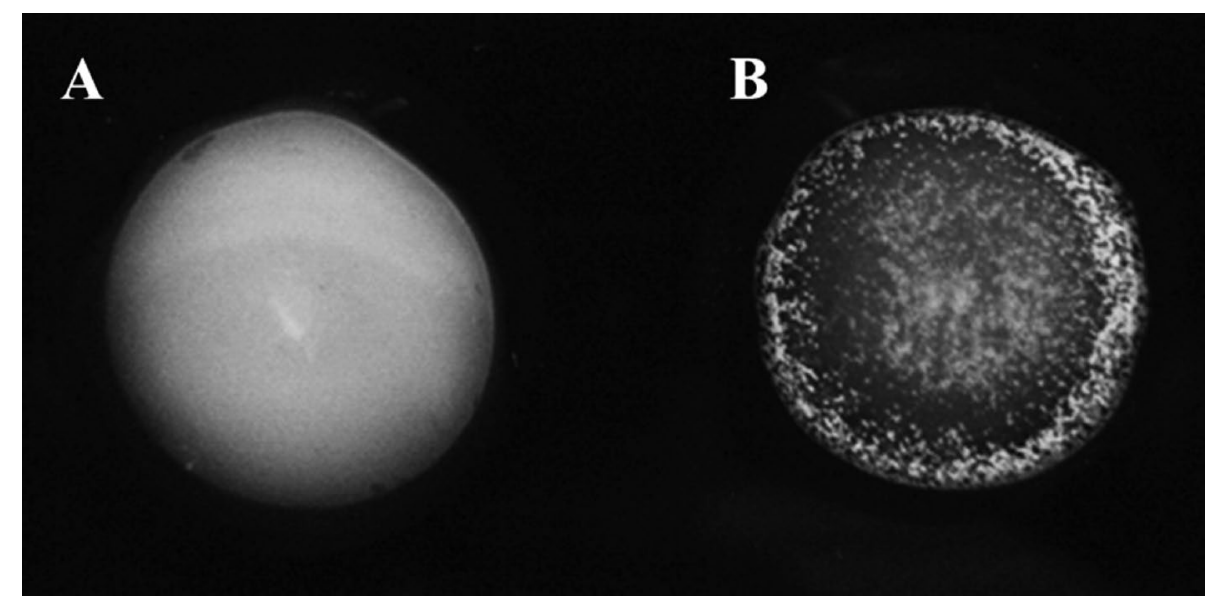

Fig. 1. Representative images from a slide agglutination test with rSd-Sip-coated latex beads. Fish sera are mixed with rSd-Sipcoated latex beads. Negative (A) or positive (B) reactions are observed.

performed and the agglutination titer was determined using sera collected from artificially infected fish (Table 2). Agglutination was observed in infected sera but not in non-infected sera (Fig. 1). The titers of infected sera were 8- to 512-fold. In contrast, no agglutination was observed in non-infected sera. Interestingly, the latex beads were agglutinated with sera collected from amberjack without symptoms and isolated bacteria. Further studies are required to examine the detectable period of time the agglutinating antibody can be used after fish have been infected with GCSD.

Two major Gram-positive pathogens in the genus Seriola, L. garvieae and S. iniae, have been reported (Eldar et al., 1996). Currently, most farmed amberjack are injected with a commercial vaccine against $L$. garvieae. To confirm the cross-reactivity of the rSdSip-coated latex beads with serum collected from fish immunized with a formalin-inactivated vaccine against L. garvieae and $S$. iniae, these immunized sera were also tested. Fig. 1 shows that all immunized sera did not react with the antigen-coated latex beads (negative). Therefore, sera stimulated by these Gram-positive bacteria did not cross-react with rSd-Sip. Additional studies are in progress to determine whether rSd-Sip-coated latex beads can be used to quantify the agglutination titer for fish immunized with a $S$. dysgalactiae commercial vaccine.

In this study, total 10 naturally infected fish sera collected from farmed amberjack were examined (Table 1). The latex beads were agglutinated with all infected fish sera (positive) as shown in Fig. 1. However, additional samples from fish farms must be examined to confirm the validity of the test.

To identify GCSD, PCR assays targeting the 16S$23 S$ rDNA spacer region (Forsman et al., 1997), sodA gene (Nomoto et al., 2008), and sof-FD gene (Nishiki et al., 2011) were developed. In addition, Congo-red agar medium was developed to discriminate between the col- ony coloration of GCSD and L. garvieae (Abdelsalam et al., 2009). However, these methods require bacterial isolation and incubation. GCSD infection causes serious economic losses because this infection occurs in mature fish, which are large enough to be sold in the market. Thus, the development of a rapid diagnosis method is essential. Serodiagnosis is not a time-consuming method because it does not typically require bacterial isolation and incubation. In a previous study, antibody detection by ELISA using rSd-Sip was developed (Nishiki et al., 2013). However, if an antibody from the serum of amberjack is going to be used for detection by ELISA, an anti-amberjack immunoglobulin $\mathrm{M}$ antibody must be prepared. In contrast, the latex agglutination test does not require specific antibodies and devices. We also performed the latex agglutination test using sera collected from GCSD-infected yellowtail and visible agglutination was observed (data not shown). Thus, the latex agglutination test can be applied not only to amberjack but also to yellowtail aquaculture.

The above-mentioned results suggest that the slide agglutination test using rSd-Sip-coated latex beads is an effective method to detect the agglutinating antibody against GCSD in fish. This is the first study to report the agglutinating antibody-detection method using the slide agglutination test for GCSD infection. This method is easy to perform and does not require a large number of reagents. Based on the advantages of this method, it will most likely be widely used in aquaculture as a rapid and useful tool to diagnose GCSD at pond sides.

\section{Acknowledgements}

This study was supported by a Grant-in-Aid for Scientific Research from the Ministry of Education, Culture, Sports, Science and Technology (24580272) 
and a Grant-in-Aid for Japan Society for the promotion of Science Fellows (24009057).

\section{References}

Abdelsalam, M., K. Nakanishi, K. Yonemura, T. Itami, S. C. Chen and T. Yoshida (2009): Application of Congo Red agar for detection of Streptococcus dysgalactiae isolated from diseased fish. J. Appl. Ichthyol., 25, 442-446.

Eldar, A., C. Ghhittino, L. Asanta, E. Bozzetta, M. Goria, M. Prearo and H. Berocoiver (1996): Enterococcus seriolicida is a junior synonym of Lactococcus garvieae, a causative agent of septicemia and meningoencephalitis in fish. Curr. Microbiol., 46, 664-668.

Forsman, P., A. Tilsala-Timisjarvi and T. Alatossava (1997): Identification of staphylococcal and streptococcal causes of bovine mastitis using 16S-23S rRNA spacer regions. Microbiology, 143, 3491-3500.

Hagiwara, H., R. Takano, M. Noguchi and M. Narita (2009): A study of the lesions induced in Seriola dumerili by intradermal or intraperitoneal injection of Streptococcus dysgalactiae. J. Comp. Pathol.,140, 35-40.

Hagiwara, H., R. Takano, M. Noguchi and M. Narita (2010): Lesions induced in Seriola dumerili following exposure to Streptococcus dysgalactiae by oral treatment or immersion. J. Comp. Pathol.,143, 262-267.

Nishiki, I., Y. Horikiri, T. Itami and T. Yoshida (2011): Cloning and expression of serum opacity factor in fish pathogenic Streptococcus dysgalactiae and its application to discriminate between fish and mammalian isolates. FEMS
Microbiol. Lett., 323, 68-74.

Nishiki, I., T. Minami, T. Itami and T. Yoshida (2013): Cloning and expression of a surface immunogenic protein in Streptococcus dysgalactiae isolated from fish and its application in enzyme-linked immunosorbent assays (ELISA) to diagnose $S$. dysgalactiae infections in fish. J. Fish Dis., doi: 10.1111/jfd.12180 (in press)

Nomoto, R., L. I. Munasinghe, D. H. Jin, Y. Shimahara, H. Yasuda, A. Nakamura, N. Misawa, T. Itami and T. Yoshida (2004): Lancefield group C Streptococcus dysgalactiae infection responsible for fish mortalities in Japan. J. Fish Dis., 27, 679-686.

Nomoto, R., N. Unose, Y. Shimahara, A. Nakamura, T. Hirae, K. Maebuchi, S. Harada, N. Misawa, T. Itami, H. Kagawa and T. Yoshida (2006): Characterization of Lancefield group C Streptococcus dysgalactiae isolated from farmed fish. J. Fish Dis., 29, 673-682.

Nomoto, R., H. Kagawa and T. Yoshida (2008): Partial sequencing of sodA gene and its application to identification of Streptococcus dysgalactiae subsp. dysgalactiae isolated from farmed fish. Lett. Appl. Microbiol., 46, 95-100.

Roberson, B. S. (1990): Bacterial agglutination. In "Techniques in fish immunology" (ed. by J. S. Stolen, T. C. Fletcher, D. P. Anderson, B. S. Roberson and W. B. van Muiswinkel). SOS Publications, Fair Haven, NJ, pp. 81-86.

Watari, M., S. Kim, J. Yamamoto, M. Kazama, S. Matsuoka, S. Chimura and H. Suzuki (2007): A rapid agglutination assay for canine brucellosis using antigen coated beads. J. Vet. Med. Sci., 69, 477-480. 